\title{
Sugimoto's Middle Brow and the Collective Horizon
}

Aaron Francis Ward

Faculty of Law, Toyo University

Follow this and additional works at: https://gensoken.toyo.ac.jp/japanese-society-and-culture

Part of the Art and Design Commons, Fine Arts Commons, Photography Commons, and the Sociology of Culture Commons

\section{Recommended Citation}

Ward, Aaron Francis (2021) "Sugimoto's Middle Brow and the Collective Horizon," Japanese Society and Culture: Vol. 3 , Article 1.

DOI: $10.52882 / 2434-1738-0301$

Available at: https://gensoken.toyo.ac.jp/japanese-society-and-culture/vol3/iss1/1

This Article is brought to you for free and open access by Institute of Social Sciences. It has been accepted for inclusion in Japanese Society and Culture by an authorized editor of Institute of Social Sciences. 


\title{
Sugimoto's Middle Brow and the Collective Horizon
}

\author{
Aaron Francis Ward *
}

\begin{abstract}
Is art for everyone? Although attendance at art galleries has risen rapidly at the start of the $21^{\text {st }}$ century, so too has the price of art, and the perception that art is an object of conspicuous consumption. The current paper presents a discussion of the possibilities that the photography of Hiroshi Sugimoto offers an artistic oeuvre that countenances the current state of the art market and is open to the aesthetic appreciation of a broader audience. As middlebrow mode of cultural production (Bourdieu 1996), photography is an artistic form that most people are familiar with, rendering it a medium that is broadly appreciable as a form of representation of common and cross-cultural experience. At the same time, photography can also satisfy the demands of highbrow cultural interpretation, meaning that it can act as a locus of community that provides access for a range of people to other forms of artistic culture. In particular, it is argued that Sugimoto's Seascapes present a particular body of work of a subject matter and style that can be appreciated by people of any sociocultural background. Further, the often-made comparisons between these images and Mark Rothko's multiform, colour-field paintings may offer viewers a bridge between middlebrow and highbrow culture, which has become, since Rothko's death, more conceptually and economically challenging for audiences to engage with and understand.
\end{abstract}

Keywords: Japanese Photography, Hiroshi Sugimoto, Aesthetics, Mark Rothko, Art

Introduction

Throughout the course of history, cultural production in the form of art has had relationships that have waxed and waned in its relevance to people occupying different strata in the social hierarchy (Shiner 2001). However, interest in the arts, as measured by attendance at art museums and galleries, has increased by an astonishing $59 \%$ in the past 30 years (Redmond 2019). This has occurred in tandem with the expansion of the global middle-class, mass-tourism and the market for luxury goods (MacCannell 1999; Han, Nunes, and Drèze 2010; Riello and McNeil 2016). These trends have particular resonance in Japan, which has seen a rise in its international profile as a destination for arts and culture. In 2016 Yayoi Kusama was also the only visual artist listed in Time magazine's most influential people of the year (Embuscado 2016), and in 2017, Kusama's My Eternal Soul exhibition was the most successful exhibition by attendance for a living artist with over half a million visitors in just three months (Sharpe and Silva 2018). (See Figure 1 below.) Other Japanese artists have also benefitted from this increased attention towards the local art market, including the teamLab Museum in Tokyo, which last year surpassed Amsterdam's stalwart, audience favourite, van Gogh Museum as the most popular single-artist destination in the world (Rea 2019).

※ Lecturer,Faculty of Law, Toyo University, Language anthropology, culture consumption, aesthetics. 


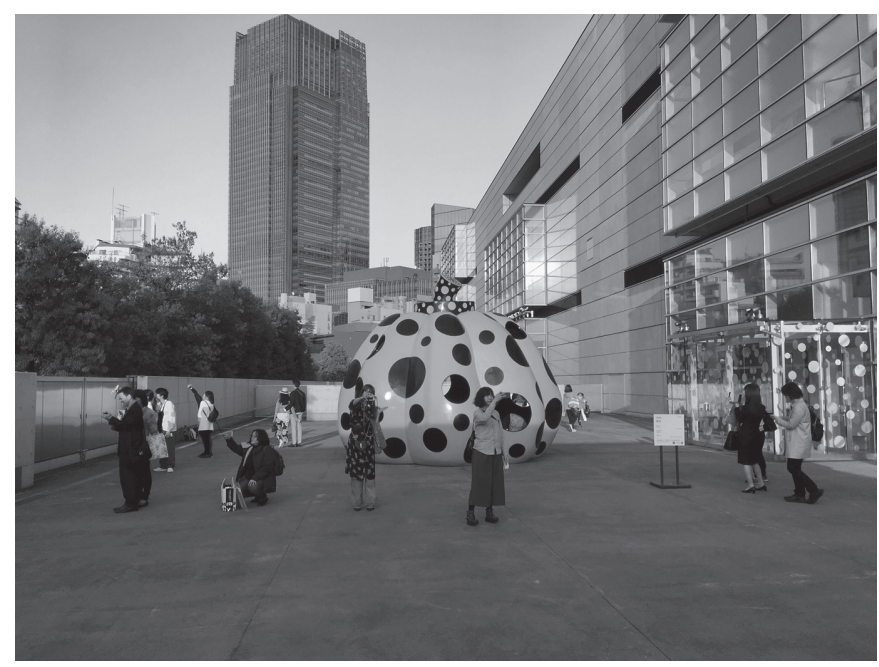

Figure 1 My Eternal Soul exhibition (2017), Yayoi Kusama (@ the author)

Although popular engagement with art has increased in the $21^{\text {st }}$ century, this is part of a process of social change that has been ongoing since at least the European Renaissance. In the Baroque period, when societies began to become more liberalized, there was a concomitant shift towards the production of art that appealed to a wider audience (Shiner 2001). This was perhaps exemplified in the Catholic paintings of Michelangelo Merisi da Caravaggio, which were used to broaden the appeal of the Catholic church to the lower tiers of society, by interpolating the suffering of the peasantry into the passion of Christian mythology (Schultze 2009; Langdon 2000). The trend of broadening art's appeal continued, particularly for religious works, until the $19^{\text {th }}$ century when the Kantian ideal of art-for-arts-sake became institutionalized as legitimate culture, and people further down the social hierarchy began to be more deliberately excluded from artistic appreciation (Shiner 2001; Hughes 2010). By the turn of the $20^{\text {th }}$ century, art museums and galleries had become more exclusive, particularly when modern art forms, such Dadaism, began to critique the traditional role of beauty in art through seminal works, such as Duchamp's (1918) production-line urinal, found-object artwork Fountain (Scruton 2009). The trend of conceptualizing modern art and intellectualizing the act of artistic appreciation, meant that art more increasingly came to be seen as a central index of social competence well into the twentieth century. Even the 1960s advent of Pop Art, which initially saw the social elevation of a popular aesthetic, quickly became opportunistic and cynical as demand on the market for Pop Art rose.

As late-capitalist societies have developed, they have progressed towards modes of cultural exchange that are geared to more refined liberalized and individuated conceptions cultural production (Deneen 2019). The primacy placed on individual autonomy has, on the one hand, diversified immanent notions aesthetic experience, but has on the other alienated more conservative and less economically empowered sections of society. By the time the twentieth century came to a close, artistic culture had begun to undermine its own aegis by making a pivotal and paradigmatic shift towards art as primarily conceptualized (Greenberg 1992; Goldie and Schellekens 2009). Central to this development was a challenge to beauty's "universal, natural, given or singular" nature that effectively and completely annexed popular aesthetic sensibilities (Beech 2009, 12; Bourdieu 1993, 1984). This was complicated by 
the increasing inclination of cultural gatekeepers to view, with suspicion, established social perceptions in art as politically loaded. This has ultimately come to mean that "private, subjective likes and dislikes [have become] inextricably caught up in social codes and social divisions." (Beech 2009, 15) Consequently, many people have become encouraged to be suspicious of beauty, and this has disallowed people the elevated experience it once was (Beech 2009).

It is not just that perceptions of what constitutes art have changed, but also its prevalence as a surrogate index of social status. In the context of the rapid expansion of the market for luxury goods (Riello and McNeil 2016); increased perceptions of art as a financial, rather than cultural, investment (Kinsella 2018); and the explosion of conspicuous consumption through online influencer culture (Hund and McGuigan 2019), the art market has ultimately turned on its communal roots (Dutton 2009). If we consider the 2017 high-profile sale of da Vinci's Salvator Mundi, for a record USD\$450m, as well as the publicity afforded to Banksy's (2018) self-shredding screen print Girl with Balloon/Love Is in the Bin (USD $\$ 1.37 \mathrm{~m}$ ) and Maurizio Cattelan's (2019) infinitely fungible, banana-duct-taped-to-wall Comedian (USD\$150,000) (Estiler 2020; Shoot 2018), it is easy to see how many people have become alienated from the cultural, communal and spiritual connections that art, for many, once offered (Scruton 2007, 2001).

\section{Photography as a Sociocultural Middle Ground}

For all of the ideological advances of modern art, it often seems to lack in its capacity to connect to tradition and broader society (Scruton 2001). The post-Kantian aesthetic of conceptual art places particular interpretive demands on the viewer that can be off-putting to a wide range of people (Bourdieu 1984, 1993; Hodge 2012). These demands mean that a large portion of modern art lacks the compelling immediateness that Arthur Schopenhauer believed was necessary to engage audiences. For Schopenhauer, the paradigmatic aesthetic experience is an immediate one where the viewer is able to lose themselves in the work and become "rivetted to the realities before him" (Vasalou 2017, 30). Further, as Friedrich Schiller implies, "[f]ulfilment does not come through purpose, [...] but only when purpose is set aside [and] the paradigm of fulfilment is the aesthetic experience [of] the disinterested contemplation of appearances, the self-conscious alertness to the presented meaning of things." (Scruton 2007, 18) For these aesthetes, art that has a wide social reach, is art which, in modern terms, suspends the of disbelief of the common viewer and in doing so engenders sympathy towards its subject matter (Walton 1980; Vasalou 2017).

If art in the $21^{\text {st }}$ century is to communicate more broadly to people, what is needed is a medium and a subject matter that can facilitate a broad consensus in people's aesthetic preferences. One such medium may be photography. Although photography is intimately connected to many of the negative aspects of modern consumer culture (Hund and McGuigan 2019), it is difficult to imagine any other medium (perhaps even those connected to necessity, such as cookery) rivalling photography in terms of its breadth of participation and production. With the advent of smartphones, most people have two-to-three cameras on them at any given time, and are at least tacitly aware of the constraints and formal qualities of photographic technique. Further, since the early $19^{\text {th }}$ century, the number of images produced has increased exponentially, indicating that photography is a medium that vast numbers of people are capable of and willing to engage with 1 . In spite of its technical constraints, photography is nonetheless grounded

1 The introduction of digital photography in the late 1990 s and social media at the start of the $21^{\text {st }}$ century have only magnified this. By 2020, an estimated 1.4 trillion images will be produced, the majority of which come from smartphones (Carrington 2020; Saracco 2016). 
in the immediate and concrete, because photographs are built from people's direct experience and the demands of everyday life (Adams 2005).

Yet, photography is not without its problems and, like jazz, as a legitimate art form has had a mixed reception since Louis Daguerre and Nicéphore Niépce exposed the first permanent photographic image in the 1830s (Shiner 2001). Although early photographers, such as Edward Weston and Edward Steichen, dedicated themselves to creating photographs as fine art, it was not until the early $20^{\text {th }}$ century that photography was accepted into art museums (Shiner 2001). Nonetheless, photography is still considered a lesser art and valued considerably less than more traditional artforms, such as painting, as determined by the market values shown in Table 1 below.

Table 1 Top Five Sales Prices in Millions for Painting and Photography

\begin{tabular}{|c|c|c|c|c|c|c|}
\hline \multicolumn{4}{|c|}{ Painting } & \multicolumn{3}{|c|}{ Photography } \\
\hline & Title & Artist & \$US & Title & Artist & \$US \\
\hline 1. & $\begin{array}{l}\text { Salvator Mundi } \\
\text { (1605) }\end{array}$ & Leonardo da Vinci & $450 \mathrm{~m}$ & $\begin{array}{l}\text { Phantom } \\
\text { (2011) }\end{array}$ & Peter Lik & $6.5 \mathrm{~m}$ \\
\hline 2. & $\begin{array}{l}\text { Interchange } \\
(1955)\end{array}$ & $\begin{array}{l}\text { Willem de } \\
\text { Kooning }\end{array}$ & $300 \mathrm{~m}$ & Rhein II (1999) & $\begin{array}{l}\text { Andreas } \\
\text { Gursky }\end{array}$ & $4.4 \mathrm{~m}$ \\
\hline 3. & $\begin{array}{l}\text { The Card Players } \\
\text { (1892) }\end{array}$ & Paul Cézanne & $250 \mathrm{~m}$ & $\begin{array}{l}\text { Untitled \#96 } \\
\text { (1981) }\end{array}$ & $\begin{array}{l}\text { Cindy } \\
\text { Sherman }\end{array}$ & $3.9 \mathrm{~m}$ \\
\hline 4. & $\begin{array}{l}\text { Nafea Fan Ipoipo } \\
\text { (1892) }\end{array}$ & Paul Gaugin & $210 \mathrm{~m}$ & $\begin{array}{l}\text { To Her Majesty } \\
\text { (1973) }\end{array}$ & $\begin{array}{l}\text { Gilbert \& } \\
\text { George }\end{array}$ & $3.8 \mathrm{~m}$ \\
\hline 5. & $\begin{array}{l}\text { Number 17A } \\
\text { (1948) }\end{array}$ & Jackson Pollock & $200 \mathrm{~m}$ & $\begin{array}{l}\text { Dead Troops } \\
\text { Talk (1992) }\end{array}$ & Jeff Wall & $3.7 \mathrm{~m}$ \\
\hline
\end{tabular}

Sources: Beale (2017); (Ricketts 2014)

The derogation of the value of photography as an artistic medium stems in no small part from its democratization (Bourdieu 1996). The advent of cheap portable cameras, such as the Kodak Brownie in the post-war era, significantly increased participation in photography, while at the same time eroding its symbolic value. The ease of access to photography, its low cost, the relative lack of time taken to acquire and execute relatively proficient photographic technique and its typical use as a medium of collective identity $^{2}$, mean that as a form of cultural production it is more likely to be taken up by working- and lower- middle-class people. This has led to photography being perceived, on the hierarchy of cultural legitimacy, as a distinctly middlebrow art (Bourdieu 1996). Further, thanks to social media platforms, such as Instagram, photography has become an almost invasive mode of participation in late-modern

2 Particularly the use of photography for family portraits and to create souvenirs of social occasions, such as weddings, birthdays and holidays. 
consumerist society (Larsen, Luna, and Peracchio 2004; Schmitt and Simonson 1997; Berger 2009; Rose 2012). ${ }^{3}$

Consequently, photography is often not considered serious art by conservative critics, such as Roger Scruton (2001). This is argued to be because, even though a photograph may take on the subject matter of fine art, such as the landscape, portrait or still life, the photographic image proper is inevitably perceived by the viewer as being indistinct from its referent (the subject contained within the image). In contrast, the production of, say, painting does not rely on the existence of its subject matter - and is thus seen as the realization of the painter's intention, and it is that which facilitates the recognition of a given painting's subject matter. From this perspective, embodied in the painted image is not only the subject matter itself, but also the artist's perception of it. Therefore, the value of a well-executed painting lies not in its replication of reality, but rather in the capacity for it to act as a 'conventional or even quasilinguistic act which stands in a semantic relation - a relation of reference - to its subject [that] presents a visual appearance only as a means of fulfilling a referential function.' (Scruton 2001, 124). As such, the painted artwork is not just seen as an image of a referent, but also an advent of the artist's perceptive and executive skill (Shiner 2001). It is these "properties of the medium [that] influence not only what is seen in the picture but also the way it is seen" and the value it is ascribed in the field of cultural production (Scruton 2001, 123; Bourdieu 1993, 1984). In contrast, the relationship between the subject matter of a photograph and what it represents is perceived to be causal - the image relies entirely on its referent's existence in the world. Consequently, the photographic image is devalued as a mechanical execution, rather than the expression of an artistic intention (Bourdieu 1996).

In spite of the many criticisms leveled against photography as legitimate art, as Table 1 indicates, it is nonetheless becoming more valued by the art market. Further, the appeal and availability of photography means that it is one area of the art market that has remained conceptually and practically accessible to a broad audience. This in turn makes photography a potential bridge across an increasingly widening social-aesthetic divide.

\section{Photography in Japan}

Japan was an early adopter of photography, and many Japanese photographers have sought to elevate photography's status as an artform through the development of technique and style. Their efforts have also included world-leading excellence in the production of photo books, as well as experimenting with printing techniques, such as Sakiko Nomura's (2016) Rencontres d'Arles International Photography Festival awarding-winning Another Black Darkness. Other photographers have sought to integrate photography into established Japanese cultural fields, such as literature and the performing arts, as can be seen in Eikoh Hosoe's (1963) seminal Barakei works with internationally-celebrated Japanese author Yukio Mishima, or Nomura's (2017) collaboration with renowned Noh actor, Koshiro Matsumoto. Further, photographers including Daido Moriyama have taken to the juxtaposition of photographic

3 A careful examination of Figure 1, shows that a significant aspect of the participation of the audience at the $M y$ Eternal Soul exhibition is the photographic opportunity. Not one of the audience members is actually looking directly at the artwork. Instead, through the inevitable sharing of the photographic image they are all interpolating themselves into Kusama's pumpkin sculpture via the cameras on their mobile phones. In doing so, they are appropriating some of the cultural capital reified in Kusama's work (Bourdieu 1993). 
images with short stories by well-known Japanese authors, such as Osamu Dazai (Moriyama 2014). Some Japanese photographers have also taken to fine-art photography including Kenro Izu (2018) and Masao Yamamoto (2019) or less-commercialized records of haute-couture, such as can be seen in Takay's (2020) collaboration with avant-garde designer, Yohji Yamamoto.

However, one Japanese photographer, Hiroshi Sugimoto, has perhaps broadened the appeal of Japanese photography in a manner reminiscent of the works of the European Bauhaus and De Stijl movements, by integrating everyday and collective life experiences into his work. While Sugimoto's work is in the tradition of fine art photography, and is often reified with a sense of Japanese aesthetic, his images are nonetheless enmeshed with Western thought (Zweite 2013). Because Sugimoto's images are taken from all over the world and are of subjects recognizable to a broad audience, they are suffused with a platonic sense of beauty that Armin Zweite $(2013,6)$ suggests have an "...arresting beauty and aura cannot fail to leave a lasting impression on all those who see them."

Sugimoto was born in Tokyo, Japan in 1948, and educated at Rikkyo (St. Paul's) University, before emigrating to the New York in the mid-1970s. His contributions to the establishment of photography as a legitimate artform have been recognized widely. He received an honorary Doctor of Fine Arts from Parsons School of Design in 2000 and has been the recipient of numerous other accolades including the 2001 Hasselblad Foundation International Award in Photography (the highest distinction in the field), as well as being admitted as to the position of Officier de L'ordre des Arts et des Lettres in 2013. Sugimoto has also held exhibitions at some of the most distinguished art institutions around the world including The Carnegie Museum of Art (1991), the Museum of Contemporary Art (1995 \& 2003), Kunsthalle Basel (1995), San Francisco Museum of Modern Art (2000) and the Palais de Tokyo (2014) (Sugimoto 2020).

Sugimoto broadens the appeal of his photography by drawing on common concerns. In particular, time is the central theme of Sugimoto's photography, which resonates because time is a central feature of engagement with culture that establishes a continuity between tradition and modernity (Scruton 2007, 2001). For Sugimoto, time is perspicacious in its role in the conservation of memory and the facilitation of a sense of connectedness to community (Sugimoto 2012). The notional ebbing and flowing of time as an ocean that connects us to our collective past, present and future, has been observed in a diversity of cultures from Africa to Japan (Mita 2019). Although photographs are often seen as instantaneous snapshots of reality, this is not necessarily so. In his landmark text Camera Lucida Barthes (2006) argues that, in a world overloaded with photographs, particular images are reified with significance to the extent that they advene (reach out) to the viewer by connecting the past to the present. Barthes argues that it is a punctum (a piercing detail within an image) specific to a given viewer that connects them to their own experience and personal understanding with the photographic subject matter. However, for Sugimoto, it is the atemporality of the studium (the subject matter) of an image that advenes and animates the beholder to a suffused aesthetic experience.

Sugimoto began his oeuvre at the endpoint of modernist art (Mita 2019), and his works are primarily concerned with long-exposure, landscape and still life photography. As a child, he became fascinated with the scientific method, and his photographic execution exudes an empirical rigor (Sugimoto 2012). This, in turn, is reflected in a body of works that are conservative in their approach-a likely reflection of growing up in a conservative family and undertaking a liberal-arts, Protestant-affiliated gakuin (kindergarten to university) education (Sugimoto 2012). Sugimoto's conservatism can also be seen in his preference for using a custom-built, $19^{\text {th }}$ century-style, eight-by-ten inch, large-format box camera. 
Working this way gives Sugimoto's resulting works a formal quality akin to historical, representational painting (See 2018; Brougher 2012). Sugimoto's style of photography is generally viewed as a form of photographic minimalism. Mita (2019) describes this approach as a "[r]eductivist passion [and an] aesthetic urge to strip away and eliminate, to reject the superfluous and excessive” (Mita 2019, 7) that stands in marked contrast to contemporary conceptual and popular art. Although Sugimoto often refers to his formative experiences growing up in post-war Japan and discusses the connection between his work and Japanese culture (e.g. Sugimoto 2012), Sugimoto's reductivism and choice of studium do not particularly lend his works a substantive Japanese character.

To illustrate how Sugimoto's works may appeal to a wider audience, and in doing so, avoid much of the divisiveness of contemporary artistic culture, some discussion will be made of Sugimoto's perhaps best-known series of photographic images: Seascapes (Sugimoto 2019b). (See Figure 2)
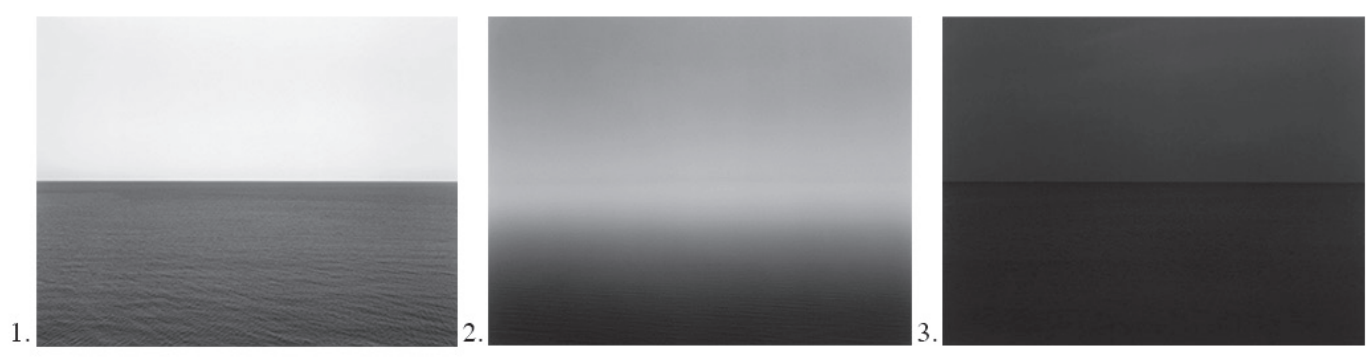

Figure 2 Seascapes 1. Caribbean Sea, Jamaica, 1980, 2. Ligurian Sea, Saviore, 1993, 3. Baltic Sea, Rügen, 1996 @ Hiroshi Sugimoto (retrieved from Sugimoto 2019a)

Sugimoto's affinity for the ocean came from a childhood experience in which he recalls how his "first view of the ocean came as an awakening... Captivated by this startling yet oddly familiar scene, I felt I was gazing on a primordial landscape.” (Sugimoto 2012, 12) The Seascapes series are an ongoing project of images taken from a variety of locations around the world, from Scandinavia, to Japan, North America and New Zealand. When exhibited, Sugimoto's Seascape images are usually printed in largescale format. (See Figure 3 on page 2.) These seascapes are uniformal, large-format photographs of the sea (and occasionally lakes) in which the horizon precisely bisects the sky and sea. Each image differs formally from others only by the length of exposure, time of day and atmospheric conditions. Although concerned with the same studium, and largely devoid of puncta, these changes in circumstantial context affect each image formally leading to at times clearly delineated, tectonic images, and at others more painterly, impressionistic ones (c.f. Wölfflin 2015; Zweite 2013). However, regardless of the presence or absence of salient details, such as clouds or waves, none of the images contain landmarks or any other context-identifying features (Wittmann 2009) —a technique that contrasts with other contemporary, longexposure, landscape photographers, such as Michael Kenna (c.f. 2015). The absence of puncta in the Seascapes images weakens their representational nature, leaving the viewer with an image that they can recognize, but not one that they can attribute to a specific experience (Wittmann 2009). 


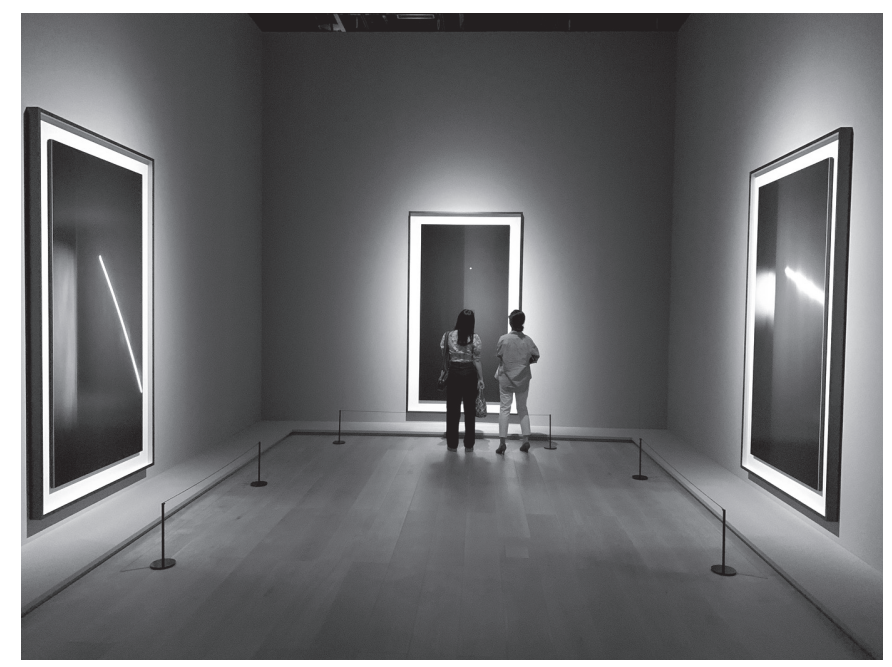

Figure 3 Hiroshi Sugimoto, Stars exhibition, Mori Art Museum (2020) (c) the author

While Sugimoto's technique is at its fundament a form of abstract and conceptual art (Zweite 2013), it in no way relies on the kinds of irony or inside joke typical of contemporary art (Scruton 2001; Goldie and Schellekens 2009). Instead, his particular use of framing and long exposure broadens the Seascapes appeal by creating a "rupture" between the studium and the resulting photograph, wherein "Sugimoto brings the image close to the real but stops just shy of persuasion." (Brougher 2012, 20) The resulting effect is not a representational, related-to-the-world snapshot of time, but rather an atemporal image that waxes and wanes in how it can be perceived (Wittmann 2009; Barthes 2006). While the images lend an air of familiarity and verisimilitude, they are not specific to the memories of any given person, and instead appeal to a collective family of resemblances (c.f. Wittgenstein 1958). In this respect, through their peculiar sublime character, Sugimoto's Seascapes facilitate the kind of aestheticization advocated by Schopenhauer and Schiller by engaging the viewer without recourse to artistic insight or the demands of Kantian contemplation (c.f. Vasalou 2017; Scruton 2007; Hughes 2010).

Sugimoto's artistic insight does not rely on technique alone. His non-culturally specific choice of subject matter is central to the aesthetic appeal of his work because it is ultimately relatable. The ocean is a source of many cross-cultural traditions, in which water is seen to support and enfold the world, making it foundational to a multiplicity of religious rites and rituals (Mita 2019). As a photographic subject matter, the ocean advenes spiritual significance and "by virtue of its size and apparent emptiness, invites our attention... [It] is too vast to understand and too awesome to avoid [and] offers a final liberation from human scale." (Adams 2005, 92) The temporal and cultural acentricity of the sea's limitless horizon means that Sugimoto's images do not require any preexisting cultural acumen to appreciate them (Mita 2019). Sugimoto also makes a more direct juxtaposition between the atemporal abstraction created by his Seascapes, and our concrete and contextualized experience of the ocean at the recently completed Enoura Observatory in Odawara. As part of his architectural design, a special 100m long gallery of Seascapes photographs is cantilevered out over the Sagami Bay, from which guests can walk outside to the same view represented in Sugimoto's celebrated images. (See Figure 4 on page 12) 


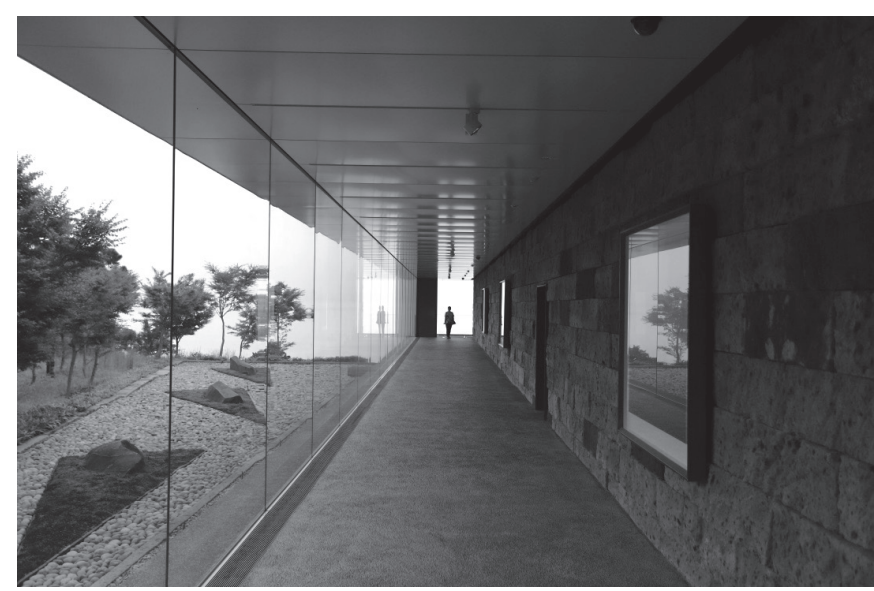

Figure 4 Enoura Observatory (2019) (ㄷ the author)

The accessibility of Sugimoto's Seascapes series also may act as a bridge for many people to engage with established highbrow art. The Seascapes have often been likened to the multiform, colour-field paintings of the late-modernist painter, Mark Rothko. The most well-known of Rothko's multiforms is No.14 (1960) (on page 13), which is part of the permanent collection at the San Francisco Museum of Modern Art.

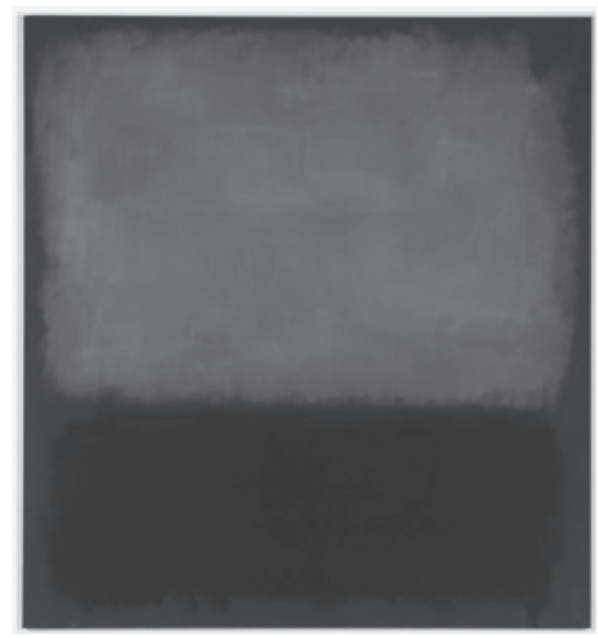

Figure 5 Mark Rothko, No. 14 (1960), San Francisco MOMA @ Kate Rothko Prizel \& Christopher Rothko

A selection of Rothko's paintings and Sugimoto's Seascapes were recently juxtaposed in an exhibition and publication through Pace Gallery in London (Pace Gallery 2012). Rothko and Sugimoto are both considered philosophical artists, who are concerned with universal notions of human emotional existence beyond the immediate moment. In these respects, Rothko's paintings can also help us to better understand our collective response to Sugimoto's Seascapes. Formally speaking, these works have a 
great deal in common. Both are comprised of powdery, emulsive, rectangular fields of varying degrees of tonal intensity and contrast. These formal elements roughly approximate the limits of human visual potential, draw the viewer into the image (c.f. Rothko 2017), and metaphorically connotate collective perceptive experience (Shiff 2012; Rothko 2015, 2017). While for Rothko, the choice of relative sharpness between the borders of the rectangular fields in each composition defines the acuity of emotional experience, these same formal distinctions in Sugimoto's photographs are a consequence of a priori decisions to shoot under particular atmospheric and lighting conditions. The presence of cloud, fog and wind and time of day affect the resulting images and are commensurate with our lived experiences in nature (Wittmann 2009; Shiff 2012). Although somewhat different in concept and execution, both sets of works express abstract, yet fundamental, human emotional and cross-cultural experience (Shiff 2012; Rothko 2015).

\section{Conclusion}

Regardless of the representational nature of Sugimoto's work, to paraphrase Christopher Rothko (2015), the reductivism of both oeuvre offer us an escape from the self-indulgences and excesses of the modern art market, exemplified in the kitsch excesses of the art-market darling, Jeff Koons. By presenting us will stripped-back experiences which we can all relate to, Sugimoto, like Rothko, is asking us to appreciate, reflect upon and share those basic things we all experience. Perhaps one of the greatest achievements of Sugimoto's photographic works in contemporary society is to help us more directly appreciate the world around us and our shared place in it. They also present, as Beech (2009) suggests, an opportunity to reconnect with beauty in a way that does not endorse a particular cultural authority. Further, if we might borrow the ideas of Basil Bernstein (2003), we could say that Sugimoto's photography satisfies the criteria of both a restricted and elaborated artistic code that is able to serve both concrete and abstract, contemplative modes of aesthetic engagement. In the words of Adams (2005, 105 - 106), beauty in photography can lead us away from the distractions of everyday life, and give "us a new understanding of and tolerance for what previously seemed anarchic and threatening." Sugimoto also reminds us that the sublime nature of experience, as presented in art, does not need to be wholly abstracted, overtly political nor cynical in order to represent and connect disparate cultures. Finally, as Christopher Rothko says of his father's work, it is the task of the artist "to fight through the natural human tendency towards complacency, superficiality and hedonism.” (Rothko 2015, 149) Hopefully, Sugimoto's Seascapes are a means to Rothko's end through a medium that can be appreciated by everyone.

\section{References}

Adams, Robert. 2005. Beauty in Photography. New York: aperture.

Barthes, Roland. 2006. Camera Lucida: Reflections on Photography. London, United Kingdom: Vintage Publishing.

Beale, Charlotte. 2017. The world's 10 most valuable artworks. Media, Entertainment and Information. Accessed June 13, 2020.

Beech, Dave. 2009. "Art and the Politics of Beauty.” In Beauty, edited by Dave Beech. Cambridge, Massachusetts: The MIT Press.

Berger, John. 2009. Ways of Seeing. London, United Kingdom: Penguin Books Ltd.

Bernstein, B. 2003. Class, Codes and Control, Volumes I - IV. 4 vols. Vol. 1-4. London: Routledge. 
Bourdieu, Pierre. 1984. Distinction: A Social Critique of the Judgment of Taste. Cambridge, Massachusetts: Harvard University Press.

-. 1993. The Field of Cultural Production. Oxford: Polity Press.

-. 1996. Photography: A Middle-brow Art. Translated by Shaun Whiteside. Oxford: Polity Press.

Brougher, Kerry. 2012. "Impossible Photography.” In Hiroshi Sugimoto, edited by Kerry Brougher and Pia Muller-Tamm. Ostfildern: Hatje Cantz Verlag.

Carrington, David. 2020. “How Many Photos Will Be Taken in 2020?” Life in Focus (blog), Mylio. August 12, 2020 .

Deneen, Patrick, J. 2019. Why Liberalism Failed. United States of America (city not specified): Yale University Press.

Dutton, D. 2009. The Art Instinct. UK: Oxford University Press.

Embuscado, Rain. 2016. Yayoi Kusama Is Only Artist Named in 'TIME's 100 Most Influential People. Accessed 12 August 2020.

Estiler, Keith. 2020. Guggenheim Now Owns Maurizio Cattelan's Taped Banana Artwork. Hypebeast. Accessed September 23, 2020.

Goldie, Peter, and Elisabeth Schellekens. 2009. Who's Afraid of Conceptual Art? London: Taylor \& Francis Ltd.

Greenberg, Clement. 1992. Art And Culture. Boston: Beacon Press.

Han, Y.J., J.C. Nunes, and X. Drèze. 2010. "Signalling Status with Luxury Goods: The role of brand prominence.” Journal of Marketing 74: 15-30.

Hodge, Susie. 2012. Why Your Five Year Old Could Not Have Done That: Modern Art Explained. London: Thames \& Hudson Ltd.

Hosoe, Eikoh. 1963. Barakei. Tokyo: Shueisha.

Hughes, Fiona. 2010. Kant's Critique of Aesthetic Judgement. First ed.Continuum Reader's Guides. London: Continuum International Publishing Group.

Hund, Emily, and Lee McGuigan. 2019. "A Shoppable Life: Performance, Selfhood, and Influence in the Social Media Storefront A Shoppable Life: Performance, Selfhood, and In" Communication, Culture and Critique 12 (1): 18 - 35.

Izu, Kenro. 2018. Seduction. Bologna: Damiani.

Kenna, Michael. 2015. Landscapes. Rome: Galleria 13.

Kinsella, Eileen. 2018. Women and Millennials Are the Fastest-Growing Forces in Art Collecting, a New Study Finds. Artnet. Accessed September 2, 2020.

Langdon, Helen. 2000. Caravaggio: A Life. London: Vintage Publishing.

Larsen, V., D. Luna, and L.A. Peracchio. 2004. "Points of View and Pieces of Time: A taxonomy of image attributes.” Journal of Consumer Research 31 (1): 102-111.

MacCannell, Dean. 1999. The Tourist: A New Theory of the Leisure Class. 1989 ed. Berkeley: University of California Press.

Mita, Munesuke. 2019. "The Horizon of Time, or a Fertile Tranquility.” In Seascapes, edited by Hiroshi Sugimoto. Bologna: Damiani.

Moriyama, Daido. 2014. Dazai. Tokyo: Match and Company.

Nomura, Sakiko. 2016. Another Black Darkness. Tokyo: Akio Nagasawa Publishing.

-. 2017. My Last Remaining Dream. Tokyo: Akio Nagasawa Publishing.

Pace Gallery. 2012. Rothko/Sugimoto - Dark Paintings and Seascapes. New York: PaceWildenstein.

Rea, Naomi. 2019. teamLab's Tokyo Museum Has Become the World's Most Popular Single-Artist Destination, Surpassing the Van Gogh Museum. Artnet News. Accessed August 10, 2020. 
Redmond, Adele. 2019. Museum and Art Gallery Attendance Bounces back. Accessed 14 August 2020.

Ricketts, Whitney. 2014. The 10 Most Expensive Photographs in the World. Creative Live. Accessed June 13, 2020.

Riello, Giorgio, and Peter McNeil. 2016. Luxury: A Rich History. Oxford: Oxford University Press.

Rose, Gillian. 2012. "photography as participation." Visual/Method/Culture (blog), Wordpress. August 15.

Rothko, Christopher. 2015. Mark Rothko: From the Inside Out. New Haven: Yale University Press.

-. 2017. "Color, Form, and Drama." In Rothko: The Color Field Paintings. San Francisco: Chronicle Books.

Saracco, Roberto. 2016. “The Digital Photography Disruption.” EIT Digital. Accessed July 22.

Schmitt, B., and A. Simonson. 1997. Marketing Aesthetics: The strategic management of brands, identity and image. New York: The Free Press.

Schultze, Sebastian. 2009. Caravaggio: The Complete Works. Los Angeles: Taschen.

Scruton, Roger. 2001. The Aesthetic Understanding : Essays in the Philosophy of Art and Culture. Indiana: St Augustine's Press.

-. 2007. Culture Counts: Faith and Feeling in a World Beseiged. New York: Encounter Books.

-. 2009. Why Beauty Matters. edited by Louise Lockwood. United Kingdom: BBC.

See, Grace Ignacia. 2018. "From Box Camera to Biennales: Six Decades of Hiroshi Sugimoto.” The Artling. The Artling. Accessed August 23, 2018.

Sharpe, Emily, and José da Silva. 2018. The world's most popular exhibition? Ancient sculptures in Tokyo versus Modern masters in Paris. The Art Newspaper. Accessed August 17, 2020.

Shiff, Richard. 2012. "Powder in the Sea." In Rothko / Sugimoto: Dark Paintings and Seascapes. London: Pace Gallery.

Shiner, Larry. 2001. The Invention of Art: A cultural history. Chicago: The University of Chicago Press.

Shoot, Brittany. 2018. Banksy ‘Girl With Balloon’ Painting Worth Double After Self-Destructing at Auction. Accessed September 23, 2020.

Sugimoto, Hiroshi. 2012. "The Times of my Youth: Images from Memory." In Hiroshi Sugimoto, edited by Kerry Brougher and Pia Muller-Tamm. Ostfildern: Hatje Cantz Verlag.

-. 2019a. "Hiroshi Sugimoto." Accessed April 9. https://www.sugimotohiroshi.com/seascapes-1.

-. 2019b. Seascapes. Second ed. Bologna: Damiani.

-. 2020. "Hiroshi Sugimoto." Accessed August 6. https://www.sugimotohiroshi.com/biography-1.

Takay. 2020. Fluence: The Continuance of Yohji Yamamoto. Bologna: Damiani.

Vasalou, Sophia. 2017. Schopenhauer and the Aesthetic Standpoint: Philosophy as a Practice of the Sublime. Cambridge: Cambridge University Press.

Walton, Kendall Lewis. 1980. “Appreciating Fiction: Suspending Disbelief or Pretending Belief.” Dispositio 5 (13-14): 1-18.

Wittgenstein, Ludwig. 1958. Philosophical Investigations. Translated by G. E. M. Anscome. Third ed. Oxford, UK: Basil Blackwell Ltd.

Wittmann, Mirjam. 2009. "Time, extended: Hiroshi Sugimoto with Gilles Deleuze." Image \& Narrative 10 (1): 176 - 198.

Wölfflin, Heinrich. 2015. Principles of Art History. Los Angeles, United States: Getty Trust Publications.

Yamamoto, Masao. 2019. Small Things in Silence. Barcelona: RM Verlag SL.

Zweite, Armin. 2013. "Foreword to Revolution.” In Revolution, edited by Hiroshi Sugimoto and Armin Zweite. Ostfildern: Hatje Cantz Verlag. 